\title{
Effect of Palliative Care Plan on Knowlegde and Practice of Children Undergoing Hemodialysis
}

\section{Prof.Amal Ahmed Khalil, Prof.Ayman Mohamed Abdel Naby Hamad, Assistant lecture.Maha Mahmoud Mahmoud Saadoon}

Professor of pediatric nursing-faculty of nursing - port said university

Professor of pediatric medicine-faculty of medicine - Mansoura university

Assisstant lecture of pediatric nursing- faculty of nursing - port said university

\begin{abstract}
Background: Involvement of pediatric palliative care for children with lifethreatening conditions and their families ideally extends throughout the illness trajectory to improve continuity of care for children and families. The aim: of this study was to determine the effect of palliative care plan on knowledge and practices of children undergoing hemodialysis. Design: A quasi-experimental research design was conducted at the hemodialysis unit of Pediatric University Hospital in Mansoura. Subjects and method: The study was carried out on 35 children whose age ranged from 8-18 years. Structured interview schedule .Selfcare questionnaire, and palliative care plan were used to collect the required data. Results: revealed that increased total mean score of patients knowledge at post test more than pre test and slightly decreased in follow up test ,with highly statistically significant differences at pre vs post test\& pre vs follow up test $(p<0.01)$ for both tests. Also shows increased total mean score of patients reported practice at post test more than pre test and slightly decreased in follow up test with highly statistically significant differences at pre vs post test\& pre vs follow up test (p $<0.01)$ for both tests. It can be concluded: that there was an improvement in studied children knowledge and practice after the implementation of the palliative care plan. So it can be recommended: that continues teaching program about palliative care for children undergoing hemodialysis are needed.
\end{abstract}

Key Words: palliative care, hemodialysis 


\section{INTRODUCTION}

Renal failure is a medical condition in which the kidneys fail to adequately filter waste products from the blood. Renal failure may occur as an acute or chronic condition. Acute renal failure (ARF) is characterized by the abrupt failure of the kidneys to regulate water and electrolyte homeostasis (Ghai et al., 2009).Chronic renal failure is a condition in which a devastating disorder associated with excessive mortality and cardiovascular morbidity but specific problems occur in children such as impaired growth and psychosocial adjustment, all of which severely had impact upon the quality of life (Shroff \& Lederman, 2009 and Rees 2009).

Advanced technology in the care of children with acute renal failure and chronic renal failure provide several renal replacement therapies (RRT) for maintaining excretory function in acute disease and for prolonged life in those with renal failure, the primary modalities are hemodialysis (HD), peritoneal dialysis (PD), hemofiltration, and transplantation emphasized that hemodialysis continues to be the most frequently utilized modality for renal replacement therapy in incident pediatric end stage renal disease (Ricci \& Kyle 2009; Chand et al., 2009). Hemodialysis affects individuals' physical and psychological well being, since it causes a number of changes in their dietary habits, social life and body appearance (Gerogia et al., 2013). Major problems in hemodialysis children are uremic symptoms and non ureamic disorders, problems in daily activity and physical function, and other problems that are induced by therapeutic procedure (Collins et al., 2009).

Palliative care is an interdisciplinary medical specialty that focuses on preventing and relieving suffering and on supporting the best possible quality of life for children and their families facing serious illness. Palliative care can be provided throughout the disease trajectory not just at the end of life and in any care setting (National Consensus Project for Quality Palliative Care 2009; Meier et al., 2015).Pediatric palliative care is based on the same principles as adult palliative care but also recognizes the unique needs of the children, the adolescents, and the families faced with a child's illness and death (Pritchard et al., 2011).

Palliative care for children is the active total care of the child's body, mind, and spirit and also involves giving support to the family. Health providers must evaluate and 
alleviate a child's physical, psychological, and social distress. Effective palliative care requires a broad multidisciplinary approach that includes the family and makes use of available community resources. It can be successfully implemented even if resources are limited. It can be provided in tertiary care facilities, in community health centers, and even in children's homes (WHO, 2010).

\section{THE AIM OF THE STUDY:}

Determine the effect of palliative care plan on the knowledge and practice of children undergoing hemodialysis.

\section{SUBJECTS AND METHOD :}

Research Design: A Quasi experimental research design was used

Setting: This study was carried out at hemodialysis unit of Pediatric University Hospital in Mansoura.

Subjects: A convenient sample of 35 children

\section{Tool for data collection:-}

The following tools were used to collect the necessary data: Structured interview sheet, self-care questionnaire, and palliative care plan.

\section{Tool I: Sociodemographic Characteristics and medical history of children undergoing hemodialysis:}

A structured interview sheet was developed and constructed by the researcher after reviewing the literature and expertise' opinions. The sheet was designed in Arabic form to avoid misunderstanding. It was includes:

\section{Part I: Children's characteristics:}

Items related to socio - demographic characteristics of the child include age, sex, level of educations, and birth order. It consists of 5 questions covering the previous items.

\section{Part II: Children's medical history:}

Items related to medical history of the child. It consisted of 14 questions covering the following items: duration of illness, causes of renal failure, having other diseases, hospitalization during the past 6 months, family medical history, kidney 
transplantation history, duration of dialysis, number of hemodialysis session/week, time schedule of session, type of vascular access, its' number, occurrence of complication due to vascular access, urination problems and problems pre, during and after dialysis session. This tool was used before the program implementation.

\section{Tool II: Self-care questionnaire:}

It was developed by Mohamed,( 2003) and Ahmed, (2000) and was modified by Ali,( 2011). This tool was used to evaluate patients' knowledge related to disease and self-care activities. It includes 23 items covering the following: Kidney functions, renal failure, function of dialysis machine, things to be considered peri dialysis, fistula care, having bleeding, edema, muscle cramps, hypertension, hypotension, itching, how to maintain healthy nutrition, protection of the body and dealing with some disease complications, exercise and regular maintenance. This tool was used before program implementation, as well as three months after program implementation.

\section{Tool IV. Palliative care planning:}

This tool was developed by the researcher for the purpose of improve children knowledge and practice.

\section{Method of study:}

The data collection started from September 2014 and extended to October 2015. This period consumed for data collection was governed by the availability time for both the researcher and the study respondents. Before conducting the study, children under study were assured that the data collected for the questionnaire remained confidential and that no personal identification was needed by any means. They also were informed that they could refuse to participate in the study, to withdraw from it at any time.

Palliative care planning implementation: was developed as the follows:

\section{Statement of the objectives}

The aim of the study was to determine the impact of palliative care plan on the knowledge and practice of children undergoing hemodialysis.

\section{Content}

Assessment and data collection phase was aimed to identify patient's problems and to have a base line assessment for patient's condition. The available previous and 
current literature, theoretical knowledge covering all aspects related the problem was done by the researcher.

Palliative care plan was designed by the researcher based actual assessment of knowledge and practice of children under hemodialysis for the purpose of improvement of knowledge and practice. The intervention was developed in a simple Arabic language to cover the relevant theoretical and practical aspects.

\section{Teaching methods and aids}

Different teaching methodology as short lecture, group discussion, role playing, demonstration, and redemonstration, was used. Also different audio visual materials were used as pamphlets, small books, diagrams picture, posters, real equipments and life situations. These were used to facilitate teaching of each topic.

\section{Implementation of the planning}

The plan implementation conducted by the researcher in 5 months .The researcher was meeting each patient individually the total number of session was (6) for each patient individually according to patients, divided as follow:(3) sessions theoretical part (renal failure and nutrition sessions, Loss of appetite and (3) sessions practical part and exercise session).

The content was repeated for each child by the researcher. The teaching hours were 3hours/day for 3 days/week for session's theoretical and practical parts. The booklet \&handouts included in the intervention were distributed to all children during planning implementation.

\section{Evaluation of the patients undergoing hemodialysis}

After program implementation, two tests were done to evaluate the effect of the program; the first post test was done immediately by the end of the program, the second was done three months after program implementation. The impact of the program was based on the improvement of common problems for children under going hemodialysis; comparing changes in their symptoms pre, post and follow up.

\section{Statistical analysis of data :}

Data were coded and transferred into specially designed formats for data entry then data were analyzed and computed. The collected data in pretest and post test were 
organized, categorized, and tabulated in tables using numbers and percentage, mean percentage and standard deviation. Chi-square $\left(\mathrm{x}^{2}\right)$ test was used to test the associations among the under studied qualitative variables, the statistical package for social sciences (SPSS version 16.0) was used for statistical analysis. Statistical significance was considered at $\mathrm{p}$-value $<0.05$.

\section{RESULTS:}

Table (1): shows distribution of the studied children according to their characteristics. This table illustrates that more than one third of the studied children $(34.3 \%)$ aged between 12 to less than 16 years with mean age of $13.91 \pm 2.60$, two third of the studied children $(60 \%)$ were male.

In relation to educational level, nearly one third of the studied children (31.4\%) were at secondary school level. Regarding birth order of the studied children, more than one third of the studied children (37.1\%) were in second birth order.

Table (2): Shows percentage distribution of studied children undergoing hemodialysis as regards vascular access. Regarding number of vascular access, this table illustrates that, majority of studied children (91.4\%) had one time vascular access; two fifths of them (40\%) had complications. The most common vascular access complications as reported by studied children was edema (50\%) followed by thrombosis $(35.8 \%)$.

Table (3): Shows total mean score of patients knowledge as regards chronic renal failure \& its management at pre, post and follow up implementation. This table revealed, increased mean score of patients knowledge at post test than pre test regarding kidney functions, function of dialysis machine, dietary regimen, diet to be avoided, protein resources, potassium rich diet resources and phosphorus rich diet resources with mostly highly statistically significant differences at pre vs post test \& pre vs follow up test $(\mathrm{p}<0.01)$.Concerning total knowledge mean score related to chronic renal failure \&its management, this table shows increased total mean score of patients knowledge at post test more than pretest and slightly decreased in follow up test, with highly statistically significant differences at pre vs posttest\& pre vs follow up test $(\mathrm{p}<0.01)$ for both tests. 
Table (4): Shows total mean score of patients reported practice of self-care activities at pre, post and follow up implementation. This table shows increased patients mean score of reported practice of self-care activities at post than pre tests about measures to be considered for hemodialysis session, care of fistula, measures to relieve edema, to relieve dyspnea, to relieve cramps ,to relieve itching, to manage hypotension, to limit fluid /day , and protection from bleeding, dyspnea, cramps, hypertension, hypotension, and finally follow exercise with mostly highly statistically significant differences at pre vs post test $\&$ pre vs follow up test $(p<0.01)$.

Concerning total mean score of patients reported practice of self-care activities, the table shows increased total mean score of patients reported practice at post test more than pre test and slightly decreased in follow up test with highly statistically significant differences at pre vs post test\& pre vs follow up test $(\mathrm{p}<0.01)$ for both tests

Table(1): Distribution of the studied children as regards their personal characteristics.

\begin{tabular}{|c|c|c|}
\hline Characteristics & $\mathrm{No}=35$ & $\%$ \\
\hline $\begin{array}{l}\text { Age/ years } \\
8->12 \\
12->16 \\
\leq 16\end{array}$ & $\begin{array}{l}10 \\
12 \\
13\end{array}$ & $\begin{array}{l}28.6 \\
34.3 \\
37.1\end{array}$ \\
\hline Mean \pm SD & \multicolumn{2}{|c|}{$13.91 \pm 2.60$} \\
\hline $\begin{array}{l}\text { Gender : } \\
\text { Male } \\
\text { Female }\end{array}$ & $\begin{array}{l}21 \\
14\end{array}$ & $\begin{array}{l}60 \\
40\end{array}$ \\
\hline $\begin{array}{l}\text { Educational level: } \\
\text { Primary school } \\
\text { Preparatory school } \\
\text { Secondary school } \\
\text { Non school }\end{array}$ & $\begin{array}{l}10 \\
8 \\
11 \\
6\end{array}$ & $\begin{array}{l}28.6 \\
22.9 \\
31.4 \\
17.1\end{array}$ \\
\hline $\begin{array}{l}\text { birth order: } \\
\text { first } \\
\text { second } \\
\text { third } \\
\text { other }\end{array}$ & $\begin{array}{l}11 \\
13 \\
6 \\
5\end{array}$ & $\begin{array}{l}31.4 \\
37.1 \\
17.1 \\
14.4\end{array}$ \\
\hline
\end{tabular}


Table(2): Percentage distribution of studied children undergoing hemodialysis as regards vascular access.

\begin{tabular}{|c|c|c|}
\hline Vascular access characteristics & No & $\%$ \\
\hline \multicolumn{3}{|l|}{ Number of vascular $\operatorname{access}\left(\mathrm{no}_{0}=\mathbf{3 5}\right)$} \\
\hline - One time & 32 & 91.4 \\
\hline - Two times & 3 & 8.6 \\
\hline \multicolumn{3}{|l|}{ vascular access complication $(\mathrm{no}=\mathbf{3 5})$} \\
\hline - Yes & 14 & 40 \\
\hline - No & 21 & 60 \\
\hline \multicolumn{3}{|l|}{ vascular access complication types $(n==14)$} \\
\hline - Edema & 7 & 50 \\
\hline - Thrombosis & 5 & 35.8 \\
\hline - Pain & 1 & 7.1 \\
\hline - Absent of pulse & 1 & 7.1 \\
\hline
\end{tabular}


Table(3): Total mean score of studied children knowledge as regards chronic renal failure at pre ,post and follow up implementations.

\begin{tabular}{|c|c|c|c|c|c|}
\hline variables & $\begin{array}{l}\text { Pre test } \\
\text { X SD }\end{array}$ & $\begin{array}{l}\text { Post test } \\
\text { X SD }\end{array}$ & $\begin{array}{l}\text { FU test } \\
\text { X SD }\end{array}$ & $\begin{array}{l}\text { P-value } \\
\text { pre vs } \\
\text { post }\end{array}$ & $\begin{array}{l}\text { P-value } \\
\text { pre vs } \\
\text { FU }\end{array}$ \\
\hline Kidney functions & $0.26 \pm 0.56$ & $2.94 \pm 0.24$ & $2.83 \pm 0.38$ & $0.001 * *$ & $0.001 * *$ \\
\hline Def. Of renal failure & $0.11 \pm 0.32$ & $2.20 \pm 1.05$ & $2.34 \pm 0.94$ & $0.001 * *$ & $0.001 * *$ \\
\hline $\begin{array}{l}\text { Function of dialysis } \\
\text { machine }\end{array}$ & $0.51 \pm 0.74$ & $2.60 \pm 0.69$ & $2.49 \pm 0.74$ & $0.001 * *$ & $0.001 * *$ \\
\hline $\begin{array}{l}\text { Identify dietary regimen } \\
\text { component }\end{array}$ & $0.37 \pm 0.84$ & $2.94 \pm 0.24$ & $2.89 \pm 0.40$ & $0.001 * *$ & $0.001 * *$ \\
\hline Diet to be avoided & $0.57 \pm 0.70$ & $2.71 \pm 0.71$ & $2.46 \pm .89$ & $0.001 * *$ & $0.001 * *$ \\
\hline $\begin{array}{l}\text { Identify protein } \\
\text { resources }\end{array}$ & $0.37 \pm 0,77$ & $2.80 \pm 0.41$ & $2.43 \pm 0.92$ & $0.001 * *$ & $0.001 * *$ \\
\hline $\begin{array}{l}\text { Identify potassium rich } \\
\text { diet resources }\end{array}$ & $0,17 \pm 0.45$ & $2.69 \pm 0.83$ & $2.46 \pm 0.98$ & $0.001 * *$ & $0.001 * *$ \\
\hline $\begin{array}{l}\text { Identify phosphorus rich } \\
\text { diet resources }\end{array}$ & $0.23 \pm 0.60$ & $2.77 \pm 0.60$ & $2.49 \pm 0.82$ & $0.001 * *$ & $0.001 * *$ \\
\hline Total knowledge score & $2.60 \pm 3.28$ & $21.66 \pm 2.86$ & $20.37 \pm 3.30$ & $0.001 * *$ & $0.001 * *$ \\
\hline
\end{tabular}


Table (4): Total mean score of studied children reported practice of self-care activities at pre, post and follow up

\begin{tabular}{|c|c|c|c|c|c|}
\hline variables & $\begin{array}{l}\text { Pre test } \\
\text { X SD }\end{array}$ & $\begin{array}{l}\text { Post test } \\
\text { X SD }\end{array}$ & $\begin{array}{l}\text { FU test } \\
\text { X SD }\end{array}$ & $\begin{array}{l}\text { P-value } \\
\text { pre vs post }\end{array}$ & $\begin{array}{l}\text { P-value } \\
\text { pre vs } \\
\text { FU }\end{array}$ \\
\hline \multicolumn{6}{|c|}{ 1-Measures to be considered for HD session } \\
\hline Before HD session $\bullet$ & $0.88 \pm 0.86$ & $2.97 \pm 0,17$ & $2.86 \pm 0.43$ & $.000 * *$ & $.000 * *$ \\
\hline During HD session $\bullet$ & $0.74 \pm 0.85$ & $3.0 \pm 0.00$ & $2.83 \pm 0.57$ & $.000 * *$ & $.000 * *$ \\
\hline After HD session • & $1.11 \pm 1.05$ & $3.0 \pm 0.00$ & $2.83 \pm 0.57$ & $.000 * *$ & $.000 * *$ \\
\hline 2-Care of fistula & $0.62 \pm 0.82$ & $3.0 \pm 0.00$ & $2.94 \pm 0.34$ & $.000 * *$ & $.000 * *$ \\
\hline 3-Protection from bleeding & $0.05 \pm 0.23$ & $2.66 \pm 0.87$ & $2.49 \pm 0.95$ & $.000 * *$ & $.000 * *$ \\
\hline 4-Measures to relieve edema & $0.22 \pm 0.54$ & $2.77 \pm 0.62$ & $2.74 \pm 0.56$ & $.000 * *$ & $.000 * *$ \\
\hline 5-Protection from dyspnea & $0.14 \pm 0.42$ & $2.83 \pm 0.62$ & $2.38 \pm 0.51$ & $.000 * *$ & $.000 * *$ \\
\hline 6-Measures to relieve dyspnea & $0.14 \pm 0.36$ & $2.66 \pm 0.68$ & $2.49 \pm 0.82$ & $.000 * *$ & $.000 * *$ \\
\hline 7-Protection from cramps & $0.25 \pm 0.50$ & $2.80 \pm 0.58$ & $2.89 \pm 0.40$ & $.000 * *$ & $.000 * *$ \\
\hline 8-Measures to relieve cramps & $0.45 \pm 0.61$ & $1.94 \pm 0,73$ & $1.66 \pm 0.87$ & $.000 * *$ & $.000 * *$ \\
\hline 9-Measures to relieve itching & $0.28 \pm 0.57$ & $2.77 \pm 0.17$ & $2.77 \pm 0.55$ & $.000 * *$ & $.000 * *$ \\
\hline 10-Protection from hypertension & $0.17 \pm 0.38$ & $2.71 \pm 0.79$ & $2.60 \pm 0.85$ & $.000 * *$ & $.000 * *$ \\
\hline 11-Protection from hypotension & $0.17 \pm 0.38$ & $2.49 \pm 1.07$ & $2.35 \pm 1.09$ & $.000 * *$ & $.000 * *$ \\
\hline $\begin{array}{l}\text { 12-Measures to manage } \\
\text { hypotension }\end{array}$ & $0.37 \pm 0.64$ & $2.71 \pm 0.71$ & $2.57 \pm 0.85$ & $.000 * *$ & $.000 * *$ \\
\hline day/13-Measures to limit fluid & $.000 \pm .000$ & $2.69 \pm 0.87$ & $2.23 \pm 1.03$ & $.000 * *$ & $.000 * *$ \\
\hline 14-Follow exercise & $0.11 \pm 0.32$ & $0.77 \pm 0.43$ & $0.8 .0 \pm 0.41$ & $.000 * *$ & $.000 * *$ \\
\hline Total practice score & $5.77 \pm 5.75$ & $41.97 \pm 5.34$ & $39.83 \pm 6.06$ & $.000 * *$ & $.000 * *$ \\
\hline
\end{tabular}




\section{DISCUSSION}

Chronic renal failure has emerged as a serious public health problem. It is characterized by an irreversible deterioration of renal function that gradually progresses to end-stage renal disease (ESRD). Data from the United States Renal Data System (USRDS) showed that incidence of kidney failure is rising among adults and is commonly associated with poor outcomes and high cost. Moreover, in the past 2 decades the incidence of the chronic kidney failure in children has steadily increased (USRDS, 2010; Gulati et al., 2015).

Hemodialysis represents the main mode for treatment of chronic kidney failure. Patients on hemodialysis account for approximately $92 \%$ of the overall dialysis population. The incidence of pediatric patient on hemodialysis is around 15 million a year (Ahmed et al., 2010).

Therefore, the present study was carried out to measure effect of palliative care planning on knowledge and practice for children undergoing hemodialysis. The findings of present study generally indicate good response from children with improvement in their knowledge and practices regarding dialysis symptoms management. This was also reflected on their health status.

The ultimate goal of the present study was to improve the dialysis symptoms through improving their knowledge. As the results of the current study showed significant increased patients total knowledge score related to chronic renal failure, its management at post test and follow up period. El-Senousy, 2007 supported these finding and Elsayed et al., 2012 who found that there was a significant improvement immediately and three months post intervention, regarding children's knowledge about renal failure. From this perspective more children undergoing hemodialysis need continues education to help them to be aware about their health problems and to understand their disease process.

The result of the current study shows increased patients knowledge and practice in area of diet and fluid intake at post test and follow up period. The same was founded by Sayyed et al., 2012, whom studied the effect of tailored counseling for patients undergoing hemodialysis upon their self-care at El Minia city, and their result show that there was statistical significant difference between patient's practices in pre intervention, and follow-up tests in area of diet, fluid intake, daily weight. This has 
also been confirmed by other researchers who recommended that improving the level of self-management by people undergoing hemodialysis is an effective way to reduce the incidence of mortality and complications and improve quality of life (Griva et al., 2011).

Finally after the implementation of the present study intervention, the knowledge and practice of the children improved in all the aspects tested as shown by the results of the current study.

\section{CONCLUSION:}

Based on the findings of the present study, it can be concluded that there was an improvement in studied children knowledge and practice after the implementation of the palliative care plan.

\section{RECOMMENDATIONS:}

Based upon the findings of the current study, it can be recommended that dialysis units should institute palliative care programs that include pain and symptom management, advance care planning, and psychosocial and spiritual support for patients and families.

\section{REFERENCES:}

Ahmad, A.M. Allam, M.F. Habil, E.S. Metwally, E.M, Ibrahiem, M.M. Radwan, M., and El-gaafary, M.M.(2010):Development of practice guidelines for hemodialysis in Egypt. Indian Journal of Nephrology; 20(4): 193-202.

Chand H, Valentini P, and Kamil S. (2009). Hemodialysis vascular access options in pediatrics: considerations for patients and practitioners. Journal of Pediatric Nephrology; 24(6): 1121-8.

Collins , A. J., Foley, R. N., Gilbertson ,D. T., Chen, S. C. (2009): The state of chronic kidney disease, ESRD, and morbidity and mortality in the first year of dialysis. Clinical Journal of the American Society of Nephrology.; 4(1), 5-111.

Elsayed, E., El-Soreety ,W., Elawany ,T., and Nasar, F.(2012): Effect of nursing intervention on the Quality of life of children undergoing 
hemodialysisLifeScienceJournal,;9(1)http://www.lifesciencesite.comhttp://www.scie ncepub.net/life 77 lifesciencej@gmail.com

Georgia ,K., Gerogiann,I., F ,P., Babatsikou,b. (2013); Identification of stress in chronic haemodialysis. Health Science Journal.; 7(2):169-76.

Ghai O, Paul V, and Bagga A.(2009). Essential Pediatrics. $7^{\text {th }}$ ed., New Delphi, USA ,pp42-6,463-6.

Griva, K., Jayasena ,D., Davenport ,A., Harrison ,M., Newman ,S.P. (2011): Illness and treatment cognitions and health related quality of life in end stage renal disease. Br J Health Psychol..;14 :17-34.

Gulati ,S., M. L., Windle, F. J., Kaskel,C., Langman, B \& Finberg, L .(2015): Chronic Kidney Disease in Children Treatment\& Management http://emedicine.medscape.com/article/984358-treatment.

Meier, D., McCormick, E., Aronld, R.M (2015):Benefits, services, and models of subspecialty palliative care .journal of palliative medicine $; 8: 1127$

Mohamed S. A. (2003): Quality of Life forPatients Undergoing Hemodialysis. D.N.Sc.Thesis, Faculty of Nursing, Ain ShamsUniversity. P.P. 92, 100-102.

National Consensus Project for Quality Paliative Care. (2009): Clinical practice guidelines for quality palliative care .2nd ed. Pittsburgh, PA: Author.

Pritchard S, Cuvelier G, Harlos M, and Barr B. (2011). Palliative care in adolescents andyoung adults with cancer. Cancer, Vol.117, No.10 suppl, 2323-8.

Rees L. (2009): Long-term outcome after renal transplantation in childhood. Journal of Pediatric Nephrology.; 24:475-84.

Ricci S, Kyle T.(2009). Maternity and pediatric nursing. Wolters Kluwer, Lippincott Williams \& Wilkins, Philadelphia, New York, pp861-54,878-88,1405-10 
Sayyed, S. A., Ali,L.M., and Mohamed ,E. R. (2012): Effect of Tailored Counseling for Patients Undergoing Hemodialysis upon Their Self-Care: Life Science Journal;9(4). 2463-71 .

Shroff, R., Ledermann, S. (2009): Long-term outcome of chronic dialysis in children. Pediatr Nephrol.;24:463-74.

US Renal Data System (USRDS). (2010) Annual Data Report: Atlas of Chronic Kidney Disease and End-Stage Renal Disease in the United States. Bethesda, M d: National Institutes of Health, National Institute of Diabetes and Digestive and Kidney Diseases; 2010. Available at http://www.usrds.org/adr.htm. Accessed: June $13,2011$.

Weisbord SD, Fried LF, Arnold RM, Rotondi AJ, Fine MJ, LevensonDJ, Switzer GE(2004): Development of a symptom assessment instrument for chronic hemodialysis patients: The Dialysis Symptom Index. Journal of Pain Symptom Manage; 27 (3): 226-40.

World Health Organization. (2010): WHO definition of palliative care. Retrievedfromhttp://www.who.int/cancer/palliative/definition/en 


\title{
تاثيرخطة الرعاية التلطيفية علي معلومات وممارسات الاطفال الخاضعين للغسيل الكلوي
}

\author{
ا.د امل احمد خليل ، ا.د. ايمن محمد عبد النبي حماد ، م.م. مها محمود محمود سعدو \\ استاذ تمريض الاطفال_ كلية التصريض- جامعة بورسعيد، استاذ طب الاطفال كلية الطب -جامعة المنصورة ، \\ مدرس مساعدـ كلبة التمريض- جامعة بورسعيد

\section{الخلاصة}

الدمج المبكرللرعاية التلطيفية للاطفال ذوي الحالات التي تهدد حياتهم وحياة أسر هم يعزز توفير الرعاية الثشاملة

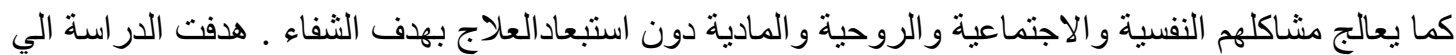
تحديد تأثير خطة الرعاية التلطيفية على المشاكل الثنائعة للأطفال الخاضعون للغسيل الكلوى ـوقد أجريت دراسة

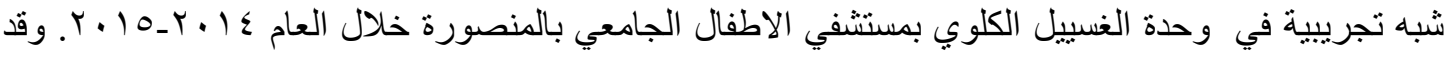

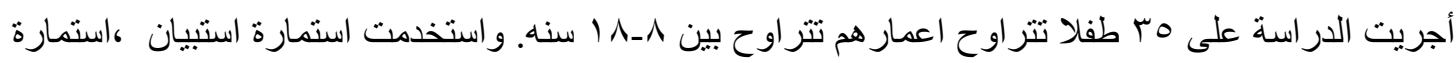
تقييم الرعاية الذاتية، مقياس اعر اض الغسيل الكلوي وخطة الرعاية التلطيفية لجمع البيانات المطلوبة. وقد وجد أن 0, 1. من الأطفال كان قد عانوا من أعر اض غسيل الكلى قبل تطبيق خطة الرعاية التلطيفية وقلت هذة

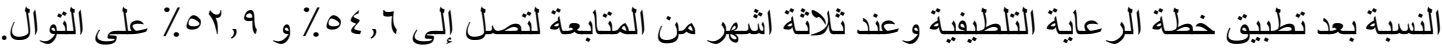

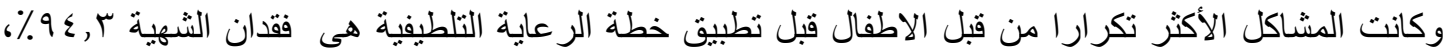

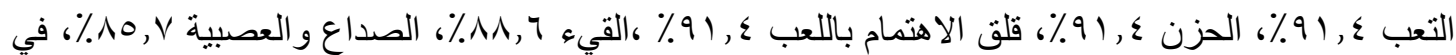

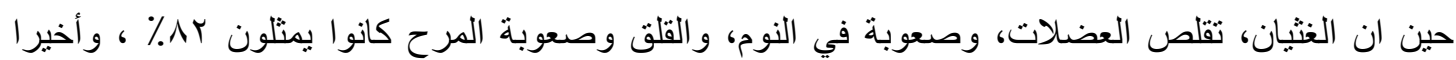
الدوخة .^٪ .ولوحظ انخفاض في كل الأعراض السابقة بعد تطبيق خطة الرعاية التلطيفية. كماأوضحت الدراسة أنه توجد علاقة ذات دلالة إحصائية فبل وبعد تطبيق خطة الرعاية التلطيفية فيما يتعلق بحدة الاعر اض السابق ذكر ها، وحدة الأعر اض الثائعة للغسيل الكلوي وحدة اجمالي أعراض الغسيل الكلوي. ومن اهم توصيات الدر اسة ان تنشئ وحدات الغسيل الكلوى بر امج للرعاية التلطيفية والتي تشمل كيفية التعامل مع الألم و الأعر اض الاخري وتقديم الدعم النفسي والاجتماعي والروحي للمرضى وأسر هم. وكذلك عمل المزيد من البحوث حول الر عاية التلطيفية للأطفال الخاضعون للغسيل الكلوي. 